\title{
MODEL TALKING STICK PADA PEMBELAJARAN MATERI KOLOID MENINGKATKAN HASIL BELAJAR DAN AKTIVITAS PESERTA DIDIK
}

\author{
Riza Afdianur ${ }^{1}$, Abdul Gani², Sulastri ${ }^{3}$ \\ ${ }^{123}$ Program Studi Pendidikan Kimia FKIP, Universitas Syiah Kuala, Darussalam Banda Aceh, Indonesia
}

\author{
A R T I C L E I N F O \\ Article history: \\ Received 19 Agustus 2020 \\ Received in revised form 19 \\ September 2020 Accepted \\ 25 September 2020 \\ Available online 2 Oktober \\ 2020
}

Kata Kunci:

Talking Stick, Hasil Belajar, Aktivitas

Keywords:

Talking Stick, Learning

Outcomes, Activities

\begin{abstract}
A B S T R A K
Pemahaman konsep yang masih kurang mengenai materi koloid terjadi karena pembelajaran di kelas masih menggunakan model pembelajaran konvesional, sehingga menyebabkan peserta didik merasa kurang bersemangat dan kurang aktif dalam mengikuti pembelajaran. Penelitian ini bertujuan untuk menganalisis aktivitas dan ketuntasan hasil belajar seta mendeskripsikan tanggapan peserta didik terhadap penerapan model pembelajaran talking stick pada materi koloid. Sampel penelitian ini adalah 35 orang siswa. Instrumen yang digunakan dalam penelitian ini yaitu lembar observasi, tes hasil belajar, dan angket. Teknik pengumpulan data dilakukan dengan cara observasi aktivitas peserta didik, tes hasil belajar dan pengisian angket tanggapan peserta didik. Hasil penelitian ini diperoleh aktivitas peserta didik pada pertemuan pertama persentase sebesar $91 \%$ dan kedua $92,25 \%$, hasil belajar peserta didik diperoleh persentase $77,41 \%$ belum tuntas dan respon
\end{abstract} peserta didik diperoleh persentase sebesar $84 \%$. Sehingga dengan menggunakan model pembelajaran talking stick pada materi koloid dapat disimpulkan bahwa aktivitas peserta didik memperoleh kategori sangat baik, hasil belajar peserta didik tidak mencapai ketuntasan, dan tanggapan peserta didik memperoleh kategori sangat baik

\begin{abstract}
The lack of understanding of the concept regarding colloid material occurs because classroom learning still uses conventional learning models, causing students to feel less enthusiastic and less active in participating in learning. This study aims to analyze the activity and completeness of learning outcomes and to describe students' responses to the application of the talking stick learning model on colloid material. The sample of this study was 35 students. The instruments used in this study were observation sheets, learning outcomes tests, and questionnaires. The data collection technique was carried out by observing the activities of students, testing the learning outcomes and filling out questionnaire responses from students. The results of this study showed that the activity of students at the first meeting was $91 \%$ and the second $92.25 \%$, the learning outcomes of students were $77.41 \%$ incomplete and the student's response was $84 \%$. So that by using the talking stick learning model on colloid material it can be concluded that the activities of students get very good categories, student learning outcomes do not achieve completeness, and the responses of students get very good categories.
\end{abstract}

\section{Pendahuluan}

Proses pembelajaran merupakan keterpaduan proses belajar dan mengajar. Proses pembelajaran yang terjadi di dalam kelas merupakan inti dari proses pendidikan, sehingga perbaikan mutu harus dimulai dengan menata dan meningkatkan mutu pembelajaran di kelas agar dapat menunjang keberhasilan pembelajaran. Keberhasilan suatu pembelajaran tidak lepas dari peran guru sebagai pengajar sekaligus sebagai narasumber bagi peserta didiknya. Guru tidak hanya menyampaikan isi buku atau referensi lain, akan tetapi juga harus dapat merencanakan pembelajaran dengan baik, pengelolaan kelas, pendekatan yang digunakan hingga model pembelajaran dan alat peraga yang akan membantu jalannya pembelajaran yang tentunya akan membuat peserta didik senang dan aktif sehingga kelas menjadi hidup (H. Sutarno et al., 2011; Umar, 2019). 
Pada hakekatnya suatu pembelajaran haruslah menggunakan media dan model pembelajaran yang inovatif dan sesuai dengan kondisi kelas, karena hal tersebut mampu membuat peserta didik lebih minat, kreatif dan aktif dalam pembelajaran (Indayatmi, 2017; E. Sutarno \& Mukhidin, 2013). Dengan adanya model yang inovatif dalam pembelajaran akan mendorong peserta didik untuk lebih menguasai materi sehingga dapat meningkatkan hasil belajar peserta didik lebih baik lagi.

Untuk mendapatkan hasil belajar yang baik maka diperlukan aktivitas yang baik. Menurut (Risvanelli, 2017; Widodo, 2014), aktivitas belajar merupakan suatu kegiatan yang dilakukan untuk menghasilkan perubahan pengetahuan-pengetahuan, nilai, nilai sikap dan keterampilan pada peserta didik sebagai latihan yang dilaksanakan secara sengaja. Tanpa adanya aktivitas maka proses belajar tidak mungkin berlangsung dengan baik. Aktivitas belajar peserta didik sangat tergantung pada lingkungan belajar, semakin kondusif lingkungan belajarnya, maka peserta didik dapat belajar lebih efektif dan aktivitas belajar memperoleh sukses dengan adanya peningkatan hasil belajar (Nurbaity et al., 2010; Yoserizal \& Rahmi, 2019). Dengan adanya aktivitas peserta didik maka terciptalah suasana belajar yang aktif. Belajar aktif adalah mengoptimalkan penggunaan semua potensi yang dimiliki oleh peserta didik sehingga semua peserta didik dapat mencapai hasil belajar yang memuaskan sesuai dengan karakteristik pribadi yang mereka miliki (Nurbaity et al., 2010; Wirawan, 2014).

Permasalahan yang terdapat di MAN 3 Banda Aceh yang dihadapi oleh peserta didik dalam pembelajaran kimia yaitu pemahaman konsepnya yang masih kurang salah satunya adalah materi koloid. Hal ini diketahui berdasarkan data ujian nasional untuk presentase penguasan materi pada materi koloid dua tahun terakhir masih tergolong rendah karena dari tahun 2016 sampai tahun 2017 menurun.Pemahaman konsep pada materi koloid dua tahun terakhir semakin menurun yaitu dari 64.5 menjadi 50.0 dan jumlah peserta didik yang memilih materi koloid dua tahun terakhir juga sangat menurun dari 79 menjadi 4 sehingga hasil belajarnya juga menurun. Maka dapat disimpulkan bahwa hasil belajar peserta didik pada materi koloid tidak mencapai kriteria ketuntasan minimal (KKM) sebesar 80, dimana dari 36 peserta didik yang ada dikelas XI MIA 1 hanya 10 peserta didik yang dapat mencapai KKM sedangkan 25 lainnya tidak mencapai KKM.

Berdasarkan hasil wawancara dengan pendidik yaitu peserta didik hanya memindahkan catatan dan pembelajaran yang terjadi di dalam kelas masih menggunakan model pembelajaran konvesional, sehingga menyebabkan peserta didik merasa kurang bersemangat dan kurang aktif dalam mengikuti pembelajaran. Salah satu solusi untuk mengatasi masalah tersebut adalah dengan cara menggunakan model pembelajaran yang inovatif. Model pembelajaran adalah suatu rencana atau pola yang dapat digunakan untuk membentuk kurikulum, merancang bahan-bahan pembelajaran, dan membimbing pembelajaran dikelas atau yang lain (Astuti et al., 2018; Linuwih \& Sukwati, 2014).

Salah satu model yang dapat digunakan adalah model pembelajaran talking stick. Model pembelajaran talking stick merupakan proses pembelajaran dengan mendorong peserta didik untuk mengemukakan pendapat. Menurut (Maharani, 2012; Sari, 2017), talking stick adalah model pembelajaran dilakukan dengan bantuan tongkat, siapa yang memegang tongkat wajib menjawab pertanyaan dari guru setelah peserta didik mempelajari materi pokoknya. Pembelajaran diawali dengan penjelasan guru mengenai materi pokok yang akan dipelajari. Peserta didik diberi kesempatan untuk membaca dan mempelajari materi tersebut. Selanjutnya guru meminta peserta didik untuk menutup bukunya. Kemudian guru mengambil tongkat yang telah dipersiapkan dan tongkat diberikan kepada salah satu peserta didik. Peserta didik yang menerima tongkat tersebut diwajibkan menjawab pertanyaan dari guru.

Kelebihan model talking stick dibandingkan model pembelajaran pada umumnya yaitu, model ini menciptakan suasana belajar yang menyenangkan karena mengkolaborasikan permaianan didalam pembelajaran, selain itu dapat memotivasi keberanian, keterampilan siswa, memupuk tanggung jawab serta melatih siswa untuk mengeluarkan pendapat sendiri, agar siswa berpikir sendiri mengasah kemampuan dan pengalaman siswa (Siregar, 2015; Ulya et al., 2020).

Model pembelajaran talking stick ini juga memberikan pengalaman belajar yang baru dan menyenangkan untuk peserta didik. Penelitian ini didukung dengan penelitian sebelumnya seperti yang telah dilakukan oleh (Siregar, 2015), hasil penelitian dari tes hasil belajar dengan menggunakan model pembelajaran talking stick memberikan hasil yang lebih baik dan aktivitas visual siswa pada konsep sistem indra, yang membedakan dengan penelitian ini adalah pada materi koloid. Selanjutnya penelitian oleh (Isnaeni et al., 2018) menyatakan bahwa pembelajaran dengan menggunakan model talking stick dapat meningkatkan hasil belajar matematika siswa, yang membedakan dengan penelitian ini adalah mengukur hasil belajar dan aktivitas siswa. Dan penelitian oleh (Wirawan, 2014) yang memperoleh hasil penelitian bahwa pengaruh penggunaan model pembelajaran talking stick aktivitas belajar dan hasil belajar pada mata 
pelajaran ekonomi, yang membedakan dengan penelitian ini adalah materi koloid. Oleh karena itu peneliti ingin menerapkan model pembelajaran talking stick ini pada materi koloid di MAN 3 Banda Aceh.

Berdasarkan latar belakang, maka telah dilakukan penelitian yang bertujuan untuk mengenalisis penerapan model pembelajaran talking stick pada materi koloid untuk meningkatkan hasil belajar dan aktivitas peserta didik kelas XI MIA 1 MAN 3 Banda Aceh.

\section{Metode}

Pendekatan yang digunakan dalam penelitian ini adalah pendekatan kualitatif. Pendekatan kualitatif adalah pendekatan yang digunakan untuk meneliti pada kondisi objek yang alamiah (Sugiyono, 2008). Jenis penelitian yang digunakan adalah penelitian deskriptif. Penelitian deskriptif bertujuan untuk menyelidiki keadaan, kondisi, situasi, peristiwa, kegiatan dan selanjutnya dipaparkan dalam bentuk laporan. Penelitian ini berfokus pada hasil belajar peserta didik, aktivitas peserta didik dan respons peserta didik terhadap penerapan model pembelajaran talking stick pada materi koloid.

Populasi dalam penelitian ini adalah seluruh peserta didik kelas XI MIA 1 MAN 3 Banda Aceh Tahun 2019/2020. Sampel penelitian ini adalah 35 orang siswa terdiri dari 18 laki-laki dan 18 perempuan. Pemilihan kelas dilakukan berdasarkan metode purposive sampling yaitu berdasarkan pertimbangan waktu penelitian dan wawancara dengan guru bidang studi kimia di sekolah tersebut.

Teknik pengumpulan data dilakukan dengan cara observasi sikap peserta didik, tes hasil belajar, dan lembar angket tanggapan peserta didik. Observasi sikap peserta didik digunakan untuk mengamati sikap peserta didik di kelas selama proses pembelajaran berlangsung untuk setiap kali pertemuan. Pengisian lembar observasi dilakukan dengan memberikan tanda check-list $(\checkmark)$. Tes hasil belajar diberikan setelah proses pembelajaran selesai pada pertemuan III. Tes ini diberikan untuk mengetahui hasil belajar peserta didik dan seberapa jauh pemahaman peserta didik tentang materi yang diberikan. Angket tanggapan diberikan kepada peserta didik untuk mendapatkan tanggapan dari peserta didik mengenai kegiatan pembelajaran pada materi koloid dengan menggunakan modeltalking stick.

Instrumen penelitian ini menggunakan lembar observasi sikap peserta didik, lembar soal tes hasil belajar, dan lembar angket tanggapan peserta didik. Instrumen tersebut terlebih dahulu dianalisis oleh dua validator yaitu dosen jurusan pendidikan kimia Universitas Syiah Kuala.

Teknik analisis data penelitian ini dilakukan dengan analisis soal secara kualitatif, aktivitas peserta didik, tes hasil belajar peserta didik dan angket tanggapan peserta didik. Analisis ini dilakukan bertujuan untuk mengenalisis penerapan model pembelajaran talking stick pada materi koloid untuk meningkatkan hasil belajar dan aktivitas peserta didik kelas XI MIA 1 MAN 3 Banda Aceh.

\section{Hasil dan pembahasan}

Berdasarkan hasil penelitian tentang penerapan model pembelajaran talking stick pada materi koloid yang dilaksanakan di MAN 3 Banda Aceh kelas XI MIA1 pada tanggal 11 April 2019 dengan jumlah peserta didik 36 orang. Data yang diperoleh dari penelitian ini berupa aktivitas peserta didik, respon peserta didik, dan hasil belajar peserta didik terhadap penerapan model pembelajaran talking stick.

Pengamatan aktivitas peserta didik selama kegiatan pembelajaran berlangsung dengan penerapan model pembelajaran talking stick pada materi koloid dilaksanakan dalam tiga kali pertemuan di kelas XI MIA 1. Pengamatan aktivitas peserta didik dapat diukur dengan menggunakan lembar observasi aktivitas peserta didik. Lembar observasi aktivitas peserta didik dapat diisi oleh tiga observer yaitu satu guru mata pelajaran kimia dan dua mahasiswa FKIP kimia unsyiah. Data hasil pengamatan dari ketiga pengamat dihitung dengan menggunakan persentase. Data persentase observasi aktivitas peserta didik pada pertemuan pertama dan kedua dengan menggunakan model pembelajaran talking stick dapat dilihat pada Tabel 1. 
Tabel 1. Hasil observasi aktivitas peserta didik di kelas XI MIA 1

\begin{tabular}{|c|c|c|c|c|c|}
\hline \multirow{3}{*}{ No } & \multirow{3}{*}{ Aspek yang Diamati } & \multicolumn{2}{|c|}{ Pertemuan I } & \multicolumn{2}{|c|}{ Pertemuan II } \\
\hline & & Rata-Rata & Persentase & $\begin{array}{l}\text { Rata- } \\
\text { Rata }\end{array}$ & Persentase \\
\hline & & & & & \\
\hline 1 & $\begin{array}{l}\text { Peserta didik menjawab salam } \\
\text { dari guru kegiatan awal } \\
\text { pembelajaran }\end{array}$ & 4 & 100 & 4 & 100 \\
\hline 2 & $\begin{array}{l}\text { Peserta didik berdoa dengan } \\
\text { khidmat }\end{array}$ & 4 & 100 & 4 & 100 \\
\hline 3 & $\begin{array}{l}\text { Peserta didik menjawab absen } \\
\text { dengan sigap }\end{array}$ & 4 & 100 & 4 & 100 \\
\hline 4 & $\begin{array}{l}\text { Peserta didik menjawab kabar } \\
\text { dengan baik dan santun }\end{array}$ & 3,7 & 92,5 & 4 & 100 \\
\hline 5 & $\begin{array}{l}\text { Peserta didik aktif menjawab } \\
\text { apersepsi dari guru }\end{array}$ & 3 & 75 & 3,3 & 82,5 \\
\hline 6 & $\begin{array}{l}\text { Peserta didik aktif menanggapi } \\
\text { motivasi yang diberikan guru } \\
\text { Inti }\end{array}$ & 3,7 & 92,5 & 3,3 & 82,5 \\
\hline 1 & $\begin{array}{l}\text { Peserta didik aktif mengajukan } \\
\text { pertanyaan terkait dengan } \\
\text { materi pelajaran yang } \\
\text { disampaikan oleh guru }\end{array}$ & 3 & 75 & 3 & 75 \\
\hline 2 & $\begin{array}{l}\text { Peserta didik berperan aktif } \\
\text { dalam implementasi } \\
\text { pembelajaran talking stick } \\
\text { Penutup }\end{array}$ & 4 & 100 & 4 & 100 \\
\hline 1 & $\begin{array}{l}\text { Peserta didik aktif } \\
\text { menyimpulkan materi yang } \\
\text { telah dipelajari }\end{array}$ & 3 & 75 & 3,3 & 82,5 \\
\hline 2 & $\begin{array}{l}\text { Peserta didik merespons salam } \\
\text { penutup dari guru dengan } \\
\text { sopan dan takzin }\end{array}$ & 4 & 100 & 4 & 100 \\
\hline & Jumlah & 36,4 & 910 & 36,9 & 922,5 \\
\hline & Rata-Rata & 3,64 & & 3,69 & \\
\hline & Persentase & 91 & & 92,25 & \\
\hline & Kategori & Sangat Baik & & $\begin{array}{c}\text { Sangat } \\
\text { Baik }\end{array}$ & \\
\hline
\end{tabular}

Berdasarkan Tabel 1 observasi aktivitas peserta didik pada pertemuan pertama data hasil pengamatan dari ketiga observer selama proses belajar berlangsung yang telah dihitung menunjukkan bahwa nilai persentase rata-rata sebesar 91\% dengan kategori sangat baik.

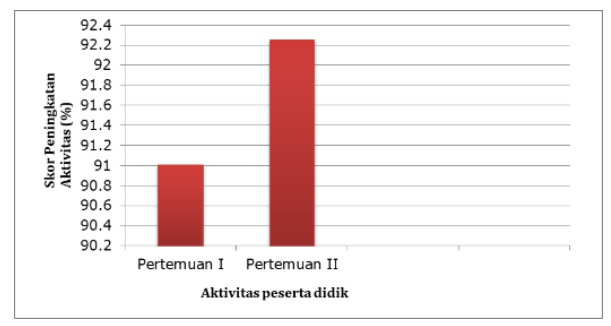

Gambar 1. Diagram Persentase Aktivitas Peserta Didik

Hasil belajar peserta didik diberikan pada pertemuan ketiga dengan menggunakan tes soal pilihan ganda sebanyak 12 butir soal. Proses belajar mengajar yang masih terpusat pada guru menyebabkan peserta didik tidak aktif dalam mengikuti pembelajaran tersebut sehingga peran guru dalam 
menyampaikan materi kimia dengan lebih menarik dan menyenangkan sehingga peserta didik akan lebih aktif. Keaktifan peserta didik ini diperlukan dalam meningkatkan hasil belajar peserta didik (Siregar, 2015; Yoserizal \& Rahmi, 2019).

Banyaknya peserta didik yang tidak tuntas dipengaruhi oleh tingginya nilai KKM di sekolah tersebut yang tidak sebanding dengan kemampuan peserta didik tersebut yang masih tergolong menengah. Namun dengan menggunakan model pembelajaran talking stick dapat meningkatkan hasil belajar dari sebelumnya. Persentase ketuntasan hasil belajar peserta didik pada penerapan model pembelajaran talking stick dapat dilihat pada Gambar 2.

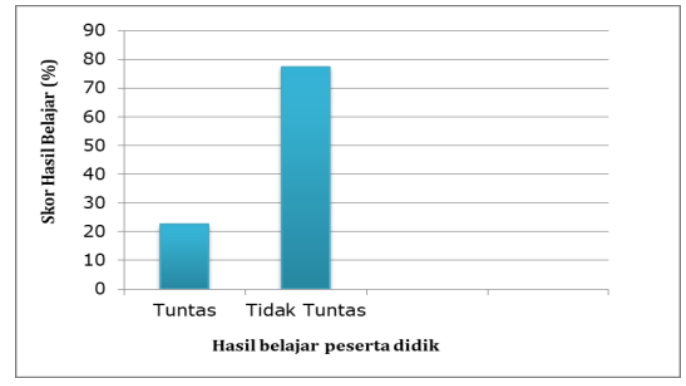

Gambar 2. Diagram Persentase Hasil Belajar Peserta Didik

Hasil respons peserta didik diberikan pada masing-masing peserta didik pada pertemuan ketiga setelah pembelajaran berakhir. Angket respons peserta didik bertujuan untuk mengetahui pendapat peserta didik terhadap model pembelajaran talking stick pada materi koloid. Angket respons peserta didik terhadap model talking stick dapat dilihat pada Tabel 2.

Tabel 2. Hasil respons peserta didik kelas XI MIA 1

\begin{tabular}{|c|c|c|c|}
\hline No & Pertanyaan & Rata-Rata & Persentase \\
\hline 1 & $\begin{array}{l}\text { Pembelajaran menggunakan model talking } \\
\text { stick pada materi koloid sangat menarik }\end{array}$ & 3,32 & 83 \\
\hline 2 & $\begin{array}{l}\text { Pembelajaran dengan model talking stick ini } \\
\text { pelaksanaannya mudah diikuti }\end{array}$ & 3,22 & 80,5 \\
\hline 3 & $\begin{array}{l}\text { Pembelajaran dengan model talking stick ini } \\
\text { memudahkan peserta didik dalam } \\
\text { memahami materi koloid }\end{array}$ & 3,45 & 86,25 \\
\hline 4 & $\begin{array}{l}\text { Suasana belajar kimia menjadi lebih } \\
\text { menyenangkan menggunakan model } \\
\text { pembelajaran talking stick }\end{array}$ & 3,29 & 82,25 \\
\hline 5 & $\begin{array}{l}\text { Pembelajaran menggunakan talking stick } \\
\text { memungkinkan peserta didik untuk lebih } \\
\text { aktif }\end{array}$ & 3,42 & 85,5 \\
\hline 6 & $\begin{array}{l}\text { Peserta didik lebih termotivasi dalam belajar } \\
\text { kimia menggunakan model pembelajaran } \\
\text { talking stick }\end{array}$ & 3,35 & 83,75 \\
\hline 7 & $\begin{array}{l}\text { Pembelajaran menggunakan model talking } \\
\text { stick dapat meningkatkan hasil belajar } \\
\text { peserta didik pada materi koloid }\end{array}$ & 3,38 & 84,5 \\
\hline 8 & $\begin{array}{l}\text { Minat belajar peserta didik dapat meningkat } \\
\text { menggunakan model pembelajaran talking } \\
\text { stick }\end{array}$ & 3,45 & 86,25 \\
\hline & $\begin{array}{c}\text { Jumlah } \\
\text { Rata-Rata } \\
\text { Persentase }\end{array}$ & $\begin{array}{c}26,88 \\
3,36 \\
84\end{array}$ & 672 \\
\hline
\end{tabular}

Berdasarkan Tabel 4.3 dapat dilihat bahwa respons peserta didik terhadap pertanyaan no 1.12 orang peserta didik yang memilih skor penilai 4. Skor paling banyak dipilih oleh peserta didik adalah no 3 
sebanyak 17 orang peserta didik, skor penilai 2 dipilih sebanyak 2 orang peserta didik, sedangkan skor penilai 1 tidak ada yang memilih sehingga persentase mencapai 83 dengan kategori sangat baik. Hal ini membuktikan bahwa pembelajaran dengan menggunakan model talking stick dapat membuat peserta didik menarik belajar pada materi koloid.

Respons peserta didik terhadap pertanyaan no 2 hanya 10 orang peserta didik yang memilih skor penilai 4 , skor penilai 3 dipilih sebanyak 18 orang peserta didik, skor penilai no 3 hanya 3 orang peserta didik yang memilih, sedangkan skor penilai 1 tidak ada peserta didik yang memilih sehingga persentase mencapai 80,5 dengan kategori sangat baik. Hal ini membuktikan bahwa peserta didik tidak mengalami kesulitan dalam proses belajar berlangsung dengan menggunakan model pembelajaran talking stick.

Respons peserta didik terhadap pertanyaan no 3 hanya 14 orang peserta didik yang memilih skor penilai 4, skor paling banyak peserta didik yang memilih yaitu skor penilai 3, sedangkan skor penilai 2 dan 1 tidak ada peserta didik yang memilih sehingga persentase mencapai 86,25 dengan kategori sangat baik. Hal ini membuktikan bahwa peserta didik lebih mudah memahami materi koloid dengan menggunakan model pembelajaran talking stick.

Pertanyaan no 4 hanya 9 orang peserta didik yang memilih skor penilai 4, sedangkan skor penilai yang paling banyak dipilih yaitu skor penilai 3 yaitu 22 orang peserta didik sehingga persentase mencapai 82,25 dengan kategori sangat baik. Hal ini membuktikan bahwa suasana belajar menjadi lebih menyenangkan dengan menggunakan model pembelajaran talking stick. Pertanyaan no 5 yang memilih skor penilai no 4 hanya 13 orang peserta didik, sedangkan skor penilai 318 orang peserta didik yang memilih sehingga persentase mencapai 85,5 dengan kategori sangat baik. Hal ini membuktikan bahwa dengan menggunakan model pembelajaran talking stick peserta didik lebih aktif dalam proses pembelajaran berlangsung.

Berdasarkan pertanyaan no 6, skor penilai 4 hanya 11 orang peserta didik yang memilih sedangkan skor penilai 3 hanya 20 orang peserta didik yang memilih sehingga persentase mencapai 83,75 dengan kategori sangat baik. Hal ini membuktikan bahwa peserta didik termotivasi belajar kimia dengan menggunakan model pembelajaran talking stick. Respons peserta didik terhadap pertanyaan no 7 hanya 12 orang peserta didik yang memilih skor penilai 4, sedangkan 19 orang peserta didik memilih skor penilai 3 sehingga persentase mencapai 84,5 dengan kategori sangat baik. Hal ini membuktikan bahwa pembelajaran menggunakan model talking stick dapat meningkat hasil belajar peserta didik pada materi koloid.

Pertanyaan terakhir yaitu pertanyaan no 8 hanya 13 orang peserta didik yang memilih skor penilai 4 , skor penilai 3 hanya 17 orang peserta didik yang memilih, sedangakan skor penilai 2 hanya 2 orang peserta didik yang memilih sehingga persentase mencapai 86,25 dengan kategori sangat baik. Hal ini membuktikan bahwa minat belajar peserta didik meningkat dengan menggunakan model pembelajaran talking stick.

Berdasarkan Tabel 3 respon penilaian peserta didik dan terhadap model pembelajaran talking stick diperoleh persentase rata-rata mencapai 84 dengan kategori sangat baik. Sehingga model pembelajaran talking stick sangat baik digunakan oleh guru dalam proses pembelajaran berlangsung. Hal ini membuat peserta didik lebih bersemangat, aktif dalam mengikuti proses pembelajaran dan lebih mudah memahami materi koloid. Persentase respon peserta didik dapat dilihat pada Gambar 3.

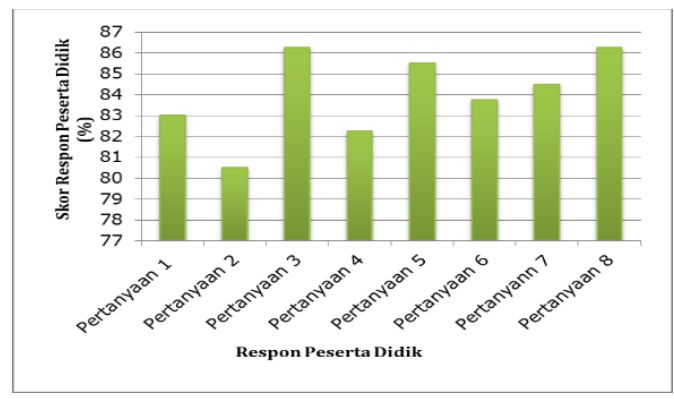

Gambar 3. Diagram presentase respon peserta didik

Pelaksanaan penelitian dilakukan selama 3 kali pertemuan berdasarkan langkah-langkah modelmodel pembelajaran talking stick yang dikemukakan oleh Surya \& Jamiah (2016), yaitu guru menyiapkan sebuah tongkah yang panjangnya $20 \mathrm{~cm}$, guru menyampaikan materi pokok yang akan dipelajari dan memberikan kesempatan kepada peserta didik untuk membaca dan mempelajari materi, setelah peserta 
didik membaca dan mempelajari materi kemudian peserta didik menutup bukunya, guru mengambilkan tongkat dan menyalakan musik kemudian peserta didik memulai menggilir tongkat dari peserta didik satu ke peserta didik yang lainnya, guru mematikan musik dan peserta didik yang memegang tongkat harus menjawab pertanyaan dari guru demikian seterusnya sampai sebagian besar mendapat bagian untuk menjawab pertanyaan dari guru, guru dan peserta didik menyimpulkan materi, dan penutup.

Pertemuan pertama dan kedua pada penerapan pembelajaran dengan menggunakan model talking stick saat proses belajar mengajar berlangsung selalu diawali membuka pembelajaran dengan salam, menanyakan kabar dan meminta ketua kelas untuk memimpin teman-teman kelasnya berdoa sebelum pembelajaran dimulai kemudian guru mengecek kehadiran peserta didik dan menyiapkan peserta didik untuk belajar. Kemudian guru memberikan apersepsi yang dilakukan dengan mengingatkan kembali pada materi sebelumnya. Hal ini dilakukan guru untuk menimbulkan perhatian peserta didik agar terpusat pada hal-hal yang akan dipelajari. Hal ini sesuai dengan pendapat (Boinah, 2017) yang menyatakan bahwa kegiatan memberikan apersepsi adalah kegiatan yang dilakukan oleh guru untuk menciptakan suasana siap mental dan menimbulkan perhatian peserta didik agar terpusat pada hal-hal yang akan dipelajari. Selanjutnya guru memberikan motivasi kepada peserta didik dengan cara menjelaskan manfaat mempelajari materi koloid. Kemudian guru menyampaikan tujuan pembelajaran yang ingin dicapai sehingga peserta didik terarah dalam aktivitas belajar. Selanjutnya guru menyampaikan topik materi yang akan dipelajari dan menjelaskan materi yang akan belajarkan. Setelah menjelaskan materi kemudian memberikan kesempatan kepada peserta didik untuk membaca dan mempelajari materi. Setelah semua peserta didik membaca dan mempelajari selanjutnya meminta peserta didik untuk menutup bukunya.

Selanjutnya guru mengarahkan peserta didik tentang cara dan aturan bermain model talking stick, kemudian peserta didik dan guru memainkan permainan. Guru mengambilkan tongkat dan memberikan salah satu peserta didik dan menyalakan musik kemudian peserta didik memulai menggilir tongkat dari peserta didik satu ke peserta didik lainnya. Selanjutnya guru mematikan musik dan peserta didik yang memegang tongkat menjawab pertanyaan dari guru. Suasana kelas pada saat permainan menjadi ribut dan siswa menjadi lebih aktif. Kemudian peserta didik yang tidak bisa menjawab pertanyaan, guru memberikan hukuman. Setelah bermain guru dan peserta didik menyimpulkan materi yang dipelajari. Hal ini sesuai dengan pendapat (Wulandari et al., 2018) yang menyatakan bahwa dalam kegiatan penutup, guru bersamasama dengan peserta didik membuat rangkuman/simpulan pelajaran. Kemudian guru menyampaikan materi pertemuan selanjutnya.

Pertemuan ketiga guru dan peserta didik melakukan praktikum, kemudian peserta didik dibagi dalam beberapa kelompok yang terdiri dari 6 peserta didik. Fungsi kelompok untuk lebih mendalami materi bersama teman kelompoknya agar bekerja dengan baik pada saat menjawab pertanyaan. Kemudian guru membagikan LKPD kepada setiap kelompok untuk didiskusikan bersama dengan kelompoknya. Selanjutnya peserta didik melakukan praktikum dan suasana kelas pada saat praktikum menjadi ribut karena peserta didik senang dan aktif. Setelah melakukan praktikum salah satu dari setiap kelompok dipilih untuk mempresentasikan hasil praktikum di depan kelas. Selanjutnya guru mengarahkan untuk mengumpulkan LKPD kedepan kelas. Kemudian guru membagikan soal tes dan angket tanggapan kepada peserta didik dan memberikan waktu lebih kurang 35 menit untuk menjawab soal tes dan angket tanggapan. Kemudian guru mengarahkan kepada peserta didik untuk mengecek kembali jawaban soal tes dan angket tanggapan yang telah dikerjakan. Kemudian guru menyuruh seluruh peserta didik mengumpulkan soal tes dan angket tanggapan ke depan kelas. Selanjutnya guru mengarahkan kepada setiap kelompok untuk mencuci alat praktikum dan guru mengakhiri pembelajaran dengan salam.

Salah satu model yang dapat digunakan adalah model pembelajaran talking stick. Model pembelajaran talking stick merupakan proses pembelajaran dengan mendorong peserta didik untuk mengemukakan pendapat. Menurut (Maharani, 2012; Sari, 2017), talking stick adalah model pembelajaran dilakukan dengan bantuan tongkat, siapa yang memegang tongkat wajib menjawab pertanyaan dari guru setelah peserta didik mempelajari materi pokoknya. Pembelajaran diawali dengan penjelasan guru mengenai materi pokok yang akan dipelajari. Peserta didik diberi kesempatan untuk membaca dan mempelajari materi tersebut. Selanjutnya guru meminta peserta didik untuk menutup bukunya. Kemudian guru mengambil tongkat yang telah dipersiapkan dan tongkat diberikan kepada salah satu peserta didik. Peserta didik yang menerima tongkat tersebut diwajibkan menjawab pertanyaan dari guru.

Kelebihan model talking stick dibandingkan model pembelajaran pada umumnya yaitu, model ini menciptakan suasana belajar yang menyenangkan karena mengkolaborasikan permaianan didalam pembelajaran, selain itu dapat memotivasi keberanian, keterampilan siswa, memupuk tanggung jawab serta melatih siswa untuk mengeluarkan pendapat sendiri, agar siswa berpikir sendiri mengasah kemampuan dan pengalaman siswa (Siregar, 2015; Ulya et al., 2020). 
Model pembelajaran talking stick ini juga memberikan pengalaman belajar yang baru dan menyenangkan untuk peserta didik. Penelitian ini didukung dengan penelitian sebelumnya seperti yang telah dilakukan oleh (Siregar, 2015), hasil penelitian dari tes hasil belajar dengan menggunakan model pembelajaran talking stick memberikan hasil yang lebih baik dan aktivitas visual siswa pada konsep sistem indra, yang membedakan dengan penelitian ini adalah pada materi koloid. Selanjutnya penelitian oleh (Isnaeni et al., 2018) menyatakan bahwa pembelajaran dengan menggunakan model talking stick dapat meningkatkan hasil belajar matematika siswa, yang membedakan dengan penelitian ini adalah mengukur hasil belajar dan aktivitas siswa. Dan penelitian oleh (Wirawan, 2014) yang memperoleh hasil penelitian bahwa pengaruh penggunaan model pembelajaran talking stick aktivitas belajar dan hasil belajar pada mata pelajaran ekonomi, yang membedakan dengan penelitian ini adalah materi koloid. Oleh karena itu peneliti ingin menerapkan model pembelajaran talking stick ini pada materi koloid di MAN 3 Banda Aceh.

Berdasarkan jabaran tersebut implikasi penerapan model talking stick akan mempengaruhi proses pembelajaran karena suasana pembelajaran yang dilakukan sangatlah nyaman dan kondusif sehingga siswa mampu belajar dengan baik, tidak ada siswa yang merasa terpaksa dalam mengikuti pembelajaran dan tidak ada siswa yang merasa terbebani. Sehingga akan berdampak pada hasil belajar dan aktivitas siswa selama kegiatan pembelajaran.

\section{Simpulan dan saran}

Berdasarkan hasil penelitian yang telah dilakukan dengan menggunakan model pembelajaran talking stick pada materi koloid dapat disimpulkan bahwa dengan menggunakan model pembelajaran talking stick pada materi koloid dapat disimpulkan bahwa aktivitas peserta didik memperoleh kategori sangat baik, hasil belajar peserta didik tidak mencapai ketuntasan, dan tanggapan peserta didik memperoleh kategori sangat baik.

\section{Daftar Rujukan}

Astuti, R., Yetri, Y., \& Anggraini, W. (2018). Pengaruh Model Pembelajaran Auditory Intellectually Repetition (AIR) terhadap Kemampuan Berpikir Kritis Siswa pada Materi Kemagnetan Kelas. Indonesian Journal Of, 01(2), 1-12. https://doi.org/https://doi.org/10.24042/ijsme.v1i2.2765

Boinah, B. (2017). Upaya meningkatkan hasil belajar Pendidikan Kewarganegaraan melalui model pembelajaran talking stick. Jurnal Civics: Media Kajian Kewarganegaraan, 14(1), 1-9. https://doi.org/10.21831/civics.v14i1.14548

Indayatmi. (2017). Peningkatan Hasil Belajar Kimia Melalui Model Chemisong Pada Peserta Didik Kimia Analisis. Edusains, 9(01), 42-52. https: //doi.org/https://doi.org/10.15408/es.v9i1.2878

Isnaeni, I., Muhaemin, M., \& Hasri, H. (2018). Peningkatan Hasil Belajar Matematika Siswa dengan Menerapkan Model Pembelajaran Talking Stick. Al-Khwarizmi: Jurnal Pendidikan Matematika Dan Ilmu Pengetahuan Alam, 5(2), 131-142. https://doi.org/10.24256/jpmipa.v5i2.272

Linuwih, S., \& Sukwati, N. O. E. (2014). Efektivitas Model Pembelajaran Auditory Intellectually Repetition (AIR) Terhadap Pemahaman Siswa Pada Konsep Energi Dalam. Jurnal Pendidikan Fisika Indonesia, 10(2), 158-162. https://doi.org/10.15294/jpfi.v10i2.3352

Maharani, S. (2012). Efektivitas Model Pembelajaran Group Investigation Dan Talking Stick Terhadap Prestasi Belajar Matematika Ditinjau Dari Aspek Psikomotorik Pada Siswa Kelas VIII MTsN Karangmojo I Magetan Tahun Ajaran 2010/2011. JIPM (Jurnal Ilmiah Pendidikan Matematika), 1(1). https://doi.org/10.25273/jipm.v1i1.457

Nurbaity, Sondang, \& Utami, W. R. (2010). Meningkatkan aktivitas belajar siswa dalam IPA Terpadu menggunakan penilaian portofolio melalui lesson study di SMP sekolah alam dan sains Aljannah Jakarta. Jurnal Pendidikan Dan Kebudayaan, 16(6), 627-637. http://jurnaldikbud.kemdikbud.go.id/index.php/jpnk/article/viewFile/491/333

Risvanelli. (2017). Peningkatan Hasil Belajar dan Aktivitas Siswa Kelas V Menggunakan Pendekatan Value Clarification Technique (VCT) Pada Pembelajaran PKn di SDN 24 Batang Anai Kabupaten Padang Pariaman. JPPI Uurnal Penelitian Pendidikan Indonesia), 3(2), 44-56. https://doi.org/10.29210/02017116 
Sari, D. M. (2017). Analysis of Students' Mathematical Communication Ability By Using Cooperative Learning Talking Stick Type. Infinity Journal, 6(2), 183-194. https://doi.org/10.22460/infinity.v6i2.p183-194

Siregar, S. (2015). Pengaruh Model Pembelajaran Talking Stick Terhadap Hasil Belajar dan Aktivitas Visual Siswa pada Konsep Sistem Indra. BIOTIK: Jurnal Ilmiah Biologi Teknologi Dan Kependidikan, 3(2), 100-106. https://doi.org/10.22373/biotik.v3i2.999

Sutarno, E., \& Mukhidin. (2013). Pengembangan Model Pembelajaran Berbasis Multimedia Interaktif Pengukuran Untuk Meningkatkan Hasil Dan Kemandirian Belajar Siswa Smp Di Kota Bandung. Jurnal Pendidikan Teknologi Dan Kejuruan, 21(3), 203-218. https://doi.org/10.21831/jptk.v21i3.3258

Sutarno, H., Rohendi, D., \& Putri, G. G. (2011). Pengaruh Kompetensi Guru. Jurnal Pengajaran MIPA, 53(16), 134-14. https://doi.org/10.1017/CB09781107415324.004

Ulya, F., Rc, A. R., \& Sulistyorini, S. (2020). The Effectiveness of Project-Based Learning Model and Talking stickType of Cooperative Learning Model on the Quran-Hadith Subject Learning Outcomes. Innovative Journal of Curriculum and Educational Technology, 9(2), 87-93. https://doi.org/https://doi.org/10.15294/ijcet.v9i2.40173

Umar, J. (2019). Kompetensi Profesional Guru Qur'an Hadits Di MTsN 8 Pidie. Jurnal MUDARRISUNA, 9(2), 437-453. https://doi.org/10.22373/jm.v9i2.4126

Widodo. (2014). Strategi Peningkatan Aktivitas Jasmani Siswa Sekolah Dasar di Luar Pembelajaran Pendidikan Jasmani, Olahraga, dan Kesehatan di Indonesia. Jurnal Pendidikan Dan Kebudayaan, 20(2), 281-294. https://doi.org/10.24832/jpnk.v20i2.144

Wirawan, Y. R. (2014). Pengaruh Penggunaan Model Pembelajaran Talking Stick Terhadap Aktivitas Belajar Dan Hasil Belajar Pada Mata Pelajaran Ekonomi Kelas X DI SMA Negeri Bandarkedungmulyo Jombang Tahun Ajaran 2012/2013. EQUILIBRIUM, https://doi.org/http://doi.org/10.25273/equilibrium.v2i2.632

Wulandari, I. A. D., Suarsana, I. M., \& Pujawan, I. G. N. (2018). Model Pembelajaran Kooperatif Talking Stick, Mind Mapping, Dan Kemampuan Komunikasi Matematis. MaPan: Jurnal Matematika Dan Pembelajaran, 6(1), 82-93. https://doi.org/10.24252/mapan.2018v6n1a8

Yoserizal, \& Rahmi, U. (2019). Perbedaan Aktivitas Belajar Siswa Antara Model Cooperative Learning Tipe Snowball Throwing Dengan Tipe Think Pair Share. Jurnal Basicedu, 3(2), 1055-1064. https://doi.org/https://doi.org/10.31004/basicedu.v3i4.247 